\title{
Introduction to Research Handbook on Democracy and Development: an overview of the debates
}

\author{
Abdul-Gafaru Abdulai and Gordon Crawford
}

This book focuses on one of the most researched, debated and controversial issues in the social sciences: the relationship between democracy and socio-economic development. A series of questions have been posed over the past 60 years on this debate. Is there a mutual reinforcement between socio-economic development and democracy, a virtuous cycle in which progress in one leads to progress in the other? Or is there little or no connection between the two? Yet, even if we assume the existence of a relationship between democracy and development, questions regarding the direction of causation will remain. First, taking development as the independent variable and democracy as the dependent variable, we can ask: to what extent and in what ways does socio-economic development impact on political democracy? In other words, do higher levels of development provide conditions that enhance prospects for democratization? Second, if we reverse the relationship with the political regime becoming the independent variable, then the question becomes: what is the impact of a democratic polity on socio-economic development? In other words, do democratic regimes offer better prospects for development than authoritarian ones? From the policy perspective, another set of important questions relate to prioritization: should the achievement of socio-economic development be prioritized by countries, with the understanding that this will provide more favourable conditions for democratization? Or, alternatively, should societal energies go into establishing a democratic political system, with the expectation that this is more likely to deliver socio-economic development for the mass of the people?

Such questions have been the subject of much research in the social sciences over many decades, yet with little consensus achieved. This book does not seek to provide definitive answers to these big questions - that would be an impossible task. It does aim, however, to provide some clarification to various aspects of the complex interlinkages between democracy and socio-economic development, and to do so based on recent research undertaken by our authors. This introduction proceeds by outlining the main ways in which scholarly debates about democracy and development have evolved over the past six decades, until the contemporary time. It then introduces the contents of the book, divided into eight parts and 28 chapters.

\section{EVOLUTION OF DEBATES 1960-2020}

While debates concerning the relationship between democracy and socio-economic development remain unresolved, it is evident that dominant perspectives have emerged at different historical moments in the last half-century and more, ones that tend to emphasize the linkage in one particular direction. In the early 1960s, following the seminal work of Seymour Martin Lipset (1959), the dominant orthodoxy was that development was a requisite of democracy to put it simply, development first, democracy second. This became a prominent part of the 


\section{Research handbook on democracy and development}

knowledge system proposed by the school of modernization theorists in the 1960s and 1970s. These theorists anticipated that less developed countries would follow in the footsteps of the already industrialized countries, with modernization entailing a transition to Western-style capitalist economies and liberal democratic polities, in that order. Another seminal work of the 1960s, that of Barrington Moore (1966), came from a very different theoretical perspective, that of neo-Marxism, but shared a structural analysis with Lipset and modernization theory that the changes in the economic and social structures associated with industrial transformation were necessary before democracy could transpire. For Barrington Moore, the key structural change was the emergence of the bourgeois class, as summed up in his famous concluding phrase: 'no bourgeoisie, no democracy'. While Lipset's analysis, and that of the modernization theorists, was relatively optimistic that the 'social requisites of democracy' would be achieved through socio-economic development, in contrast, Moore traced three possible historical trajectories from agrarian societies to modern industrial ones, dependent on class formations and class alliances between the bourgeoisie, aristocracy and peasantry. The capitalist democratic route, typified by France, England and the United States, was one, but a capitalist reactionary route which engendered fascist dictatorship, as in Germany and Japan, was another, while a communist route, exemplified by Russia and China, was a third possibility. While democracy seemed preferable to different forms of dictatorship, the question of development under authoritarian rule was also raised. Here, Samuel Huntington's (1968) work on political order was somewhat controversial, including among fellow modernization theorists, with his emphasis on 'political order' as necessary for economic development and that this was more likely to be attained under authoritarian rule.

Meanwhile, at this time, where was economic growth and development actually occurring in the world? Real-world evidence offered some support, in fact, for the notion that authoritarian rule could provide favourable conditions for economic development, while also confirming the worst excesses of some authoritarian regimes, both economically and politically. By the 1980s, economic growth and industrialization was most evident in East Asia, notably in the four 'Tiger' economies of South Korea, Taiwan, Singapore and Hong Kong, under the 'developmental state' model where authoritarian governments presided over state-directed industrialization in conjunction with private sector firms (Amsden, 1989; Wade, 1990). It is well-known that South Korea had roughly the same gross domestic product (GDP) as Ghana in 1960, shortly after Ghanaian independence. Yet, by 1996, South Korea had joined the Organisation for Economic Co-operation and Development (OECD) group of wealthy nations, while Ghana remained a low-income country, and even became one of the 'highly indebted poor countries' (HIPCs) in the early 2000s as the country's democracy became increasingly consolidated (Abdulai and Crawford, 2010).

While a variety of factors may have accounted for successful industrialization in South Korea, not least substantial US government assistance, the ability of authoritarian governments to implement a long-term industrial strategy was noted, inclusive of long-term investment and planning, in contrast to the short-term electoral cycles of democracies. The subsequent democratic transitions in South Korea and Taiwan, achieved in 1987 and 1996 respectively, would appear to give some credence to the modernization thesis that advances in economic development would likely lead to the emergence of democracy. However, modernization hypotheses were severely challenged and contested by experiences elsewhere in the world. This occurred most notably in Latin America where capitalist development under conditions of dependency had led to a turn away from democratic, competitive politics in the 1960s and 
1970s (Collier, 1979, p. 20). During this period, the four most advanced industrial economies in South America were subject to military coups that overthrew democratic governments, with military regimes then continuing into the 1980s and even 1990s. Military coups occurred in the 1960s in Brazil (1964-5) and Argentina (1966-73 and again 1976-83), and then in the 1970s in Uruguay (1973-85) and Chile (1973-90), where the US-supported military coup led to the overthrow and death of elected President Salvador Allende. These military regimes were responsible for political repression and gross human rights violations, notably the 'Dirty War' and 'disappearances' in Argentina after the 1976 coup and the atrocities committed by General Pinochet's regime in Chile (1973-90). These military dictatorships were characterized as 'bureaucratic authoritarian' regimes by Guillermo O'Donnell (1973), and at times had some association with economic growth, notably in Brazil after 1964. Yet this was elite-oriented growth based on foreign capital investment and the suppression of labour unions and workers' rights. Such growth did not lead to improvements for the poor majority, but instead resulted in rising inequalities. Additionally, the economic liberalization measures introduced in Chile under Pinochet from the mid-1970s onwards, influenced by Milton Friedman and his 'Chicago boys', foretold the demise of the state-led development model and the rise of neoliberalism. Indeed, the Chilean experience under military dictatorship in the 1970s was the first experiment in neoliberalism that came to dominate the global economy in the 1980s and 1990s, with questionable implications for democracy, as discussed further in this book.

Elsewhere in the so-called developing world, various forms of autocratic rule were often disastrous for the majority population. Characterized as 'authoritarian state elite-enrichment regimes' by Georg Sorensen (1998, p. 79), various types of one-party and no-party regimes were led by personal rulers who controlled and looted the state for their own personal enrichment and that of their clientelist groups, and promoted neither growth nor the welfare of their citizens. Sorensen (1998, p. 80) gives examples in Africa such as the former Zaire (now Democratic Republic of the Congo) under Mobutu (1965-97) and the Central African Republic under Bokassa (1966-79), as well as elsewhere - for instance, Haiti under the Duvaliers (Papa Doc 1957-71, Baby Doc 1971-86).

Returning to the scholarly world, another influential volume was that of Rueschemeyer, Stephens and Stephens (1992) in their examination of the relationship between capitalist development and democracy. Their starting point was the fact that most developed countries are democracies, and they provided a class-based structural argument similar in some respects to that of Barrington Moore 25 years earlier. However, their analysis focused on a different class protagonist as responsible for the transition to democracy - the working class, not the bourgeoisie. In accounting for this, their major explanation was that socio-economic development is accompanied by a 'changing balance of class power' - namely, the enlargement of the working class as a pro-democratic force and the erosion of the power of the landowning class as the 'most anti-democratic force' (1992, p. 76). Again, as with previous structural analyses, they were seeking to explain how capitalist development and associated structural changes gave rise to democracy. However, this publication coincided with the collapse of the Soviet Union in late 1991, and a 'new orthodoxy' (Leftwich, 1996) quickly emerged in the post-Cold War context of Western triumphalism. This reversed the expected direction of influence, with much scholarly interest now turning to focus on the impact of democracy on socio-economic development.

The 'new orthodoxy' was initially associated with the political conditionality policies of bilateral and multilateral development aid 'donors' (Crawford, 2001), and emerged in the dual 
context of the collapse of communism and the 'third wave of democratization' (Huntington, 1991). Starting with the Carnation Revolution in Portugal in 1974, the 'third wave' had spread through Latin America in the 1980s, touched the Asia-Pacific region in the mid- to late 1980s, before washing across Central and Eastern Europe in the late 1980s and, finally, sub-Saharan Africa in the early 1990s. According to Huntington's classification, the number of formal democracies increased from less than 30 per cent to more than 60 per cent of countries in the world during that period (Huntington, 1997, p. 3), though, of course, there were some reversals subsequently.

The post-Cold War expectation was that the transition to a democratic political system in former communist and low-income countries would lead to more favourable outcomes in terms of economic growth and development. In subsequent years, such confidence amongst international organizations and mainstream Western scholars has declined somewhat with the inability of many transitioning countries to achieve democratic consolidation and the increased prevalence of competitive authoritarian or 'hybrid' regimes (Levitsky and Way, 2010), as well as the frequent failure of democratic regimes to deliver socio-economic development for their citizens. Nonetheless, the post-Cold War context led to a renewal of research questions about the entangled relationship between democracy and development, though now focusing more on the political regime as the independent variable and looking at the impact on socio-economic development.

Particularly noteworthy is the work of Adam Przeworski et al. (2000), Democracy and Development: Political Institutions and Well-being in the World. This provides a comprehensive examination of different aspects of the relationship between political regimes and material well-being. The authors explore various questions concerning the economic and political outcomes of democratic and autocratic regimes using a comparative method and quantitative analysis, with data on 141 countries between 1950 and 1990. One key finding is that richer countries do better in maintaining democracy, with no democratic regime having reverted to dictatorship after a certain income level has been reached (US\$6055 per capita), but the level of economic development in itself is of little consequence for democratic transition. This was presented as a challenge to modernization theory, with Przeworski et al. (2000, p. 137) concluding that: 'Modernization theory appears to have little, if any, explanatory power'. In fact, their analysis concentrates on the impact of different political regimes on aspects of development, not the other way round as modernization theory did, and their overall finding was that political regimes had limited impact on development - for instance, on economic growth.

But one exception was the strong finding concerning political regime and demography, where democracies performed significantly better than autocracies in terms of lower birth rates, higher life expectancy, and higher per capita incomes at the equivalent level of economic development. This resonates with the standout finding from various studies on the relationship between political regimes and aspects of poverty - namely, that the establishment of democracy leads to a significant decline in infant mortality rates (see Crawford and Abdulai, 2012, p. 355). Infant mortality is often taken as a key poverty indicator, given its concentration in the lowest income quintile, as well as its close relationship with other welfare measures such as nutritional levels, sanitary conditions, access to health facilities, and female education and literacy rates (Navia and Zweifel, 2000). But with the exception of infant mortality, the findings of many empirical studies, mainly quantitative, concerning the relationship between democracy and poverty reduction remain unclear and ambiguous (Crawford and Abdulai, 2012 , p. 353). Interestingly, while findings tend to confirm that democracies spend more on 
social services such as health and education, the outcomes of such spending do not necessarily translate into poverty reduction due to elite capture of such expenditure, with benefits skewed towards upper- and middle-income groups (ibid., p. 356). This pertains to the broader issue of democracy and inequality, which is discussed below.

One critical point concerning many of the quantitative studies that measure the impact of democracy on various aspects of socio-economic development, including Przeworski et al.'s (2000) influential book, is the crude binary or dichotomous classification of countries as either democratic or autocratic. While this may enable the statistical analysis, a classification based on types of democracy or degrees of democratization could provide a more accurate picture of the type of political regime that may facilitate progress in specific socio-economic development indicators. We seek to provide some clarification in this book by considering different forms and types of democracy, beginning with the definitional chapter by Skaaning, as well as varieties of autocracy, and their developmental implications.

One recent study on economic development and democracy that does disaggregate the concept of democracy into different types and constituent components is that by Knutsen et al. (2018), although they focus on examining the impact of economic development on democracy, and not the other way around. This returns to the relationship originally explored by Lipset (1959), though with more focus now on the nature of the democratic outcome. Their findings are that economic development is robustly associated with the electoral aspect of democracy, and not, or less so, with other components such as the participatory, deliberative, liberal or egalitarian aspects that are associated with broader concepts of democracy. Thus, economic development strengthens electoral democracy by shifting power resources to citizens from leaders, and by citizens using such resources to hold leaders accountable through elections (Knutsen et al., 2018). This work also provides some corroboration of Przeworski et al.'s (2000) findings. They indicate how economic development assists in upholding an existing electoral regime, thus preventing backsliding to autocracy, and supporting Przeworkski et al.'s 'survival story' that democracy is sustained in more developed countries, while economic development plays little or no role in initial democratic transitions (Knutsen et al., 2018, p. 308).

As we moved into the twenty-first century, post-Cold War Western confidence diminished regarding the universality of the model of a capitalist market economy and a liberal democratic polity. Contemporary concerns have focused on three main areas: state capacity, inequality and authoritarian populism. We look briefly at each in turn.

Perhaps the failure of the 'new orthodoxy' of the 1990s, inclusive of the realization that democracy was no 'magic bullet' and of the negative developmental outcomes of neoliberalism, led some researchers to look more carefully at the role of state capacity. This perspective tended to question any direct linkage between forms of governance (including democracies) and socio-economic development, and instead highlighted the primacy of state capacity in shaping welfare outcomes. In a quantitative study covering up to 162 countries during the period 1965-2010, Hanson (2015) concludes that although better developmental outcomes can result from either democracy or state capacity, the latter is more crucial for bringing about development. He notes that higher levels of democracy can help compensate for low levels of state capacity, but that 'When state capacity is high, development outcomes improve even in the absence of democracy' (p. 328).

In addition, the recent literature on political settlements argues similarly that state capacity for development is not so much driven by the presence of formal democratic institutions such 
as parties or elections, but rather the relative power of different groups and organizations and the extent to which those in power are vulnerable (Abdulai and Hickey, 2016; Hickey, Sen and Bukenya, 2015; Kelsall, 2013; Khan, 2010, 2018; Levy, 2014). In particular, if a ruling coalition is vulnerable to threats from excluded elite factions with significant holding power, it is more likely to be driven by short-term calculations than to undertake institutional reforms and distribute resources with a longer-term vision of the national interest in mind. It is argued that the highest levels of state capacity for development are likely to occur where the vulnerability of ruling elites is low due to the absence of powerful factions that are horizontally excluded. This level of regime security can encourage those in power to adopt a longer-term time horizon which reduces the transaction costs involved in implementing policies. Conversely, where there is a credible threat to the ruling coalition from powerful excluded groups who may be able to wrest power (either through elections or coups), and where lower-level factions are strong enough to make multiple demands on the centre, then the prospects for developmental governance over the long term are diminished. In such competitive clientelist political settlements, elite incentives tend to be loaded towards the use of public institutions in securing short-term political gains. In this book, Chapter 12 by Croissant and Pelke on the Asia-Pacific region has a particular focus on the significance of state capacity in shaping development trajectories.

The sharp rise of global inequalities in various forms over the last three decades has become a major concern, referred to as 'the defining issue of our time' by former US President Barack Obama (Sargent, 2013). Within academic research, the significance of inequality has been highlighted by authors such as Kate Pickett and Richard Wilkinson (2009) and Thomas Piketty (2014), as well as by Oxfam's 'Even It Up' report (2014), with 'reduced inequalities' adopted as one of the Sustainable Development Goals (SDG 10) in 2015. While democracy is based on the principle of 'political equality' (Beetham, 1994, p. 28), at least as expressed in the universal franchise of 'one person, one-vote', such widening wealth inequalities have often occurred in democratic contexts, and it seems that liberal democracy does little or nothing to stem inequality and exclusion. It is evident that a redistributive element is required for a positive developmental impact, yet what form of democracy is more likely to deliver that? Sorensen (1998) distinguished between 'elite-dominated democracies', which include the large majority of democratic regimes; and 'mass-dominated democracies' with the potential to deliver more redistributive and transformative policies that bring improvements to the mass of the population. However, the number of real-world examples of the latter category was limited.

It is clear that social and economic inequalities undermine democracy. Such inequalities not only deprive people of their basic needs and rights, but also disenfranchise them from the effective exercise of their citizenship (Beetham and Boyle, 1995, pp. 111-12). Additionally, wealth is used in significant ways to influence and manipulate political outcomes in ostensibly democratic processes. This key issue of 'inequalities and democracy' is addressed in Part VI of the book.

Rising inequalities are also associated with: the rise of authoritarian populism in the past decade and the crisis for liberal democracy, as noted in Chapter 21 on democracy and inequality by Rocha Menocal. The resurgence of authoritarian regimes has been highlighted in annual democracy surveys that report that 'democracy is in retreat' (The Economist, 2020) and 'under assault' (Freedom House, 2020), with the latter recording a year-on-year decline in democracy scores from 2006. More frightening is the addition of right-wing populism to authoritarian backsliding, with authoritarian leaders gaining control of the state through deploying populist 
rhetoric in electoral contests in an increasing number of polities in the past decade. Examples abound around the world, including some of the largest and most well-established democracies, notably Bolsonaro in Brazil, Duterte in the Philippines, Orbán in Hungary, Modi in India, Putin in Russia and Trump in the United States. In theory, populism can come from both the political right and left, but in practice the recent upsurge has been almost exclusively right-wing. Authoritarian populism takes different forms in different contexts, but also presents common features (McCarthy, 2019). Such common features include: an aggressive assertion of nationalism and national self-interest, often coupled with opposition to global or multilateral institutions; self-presentation as anti-establishment and anti-elite, despite often close connections to business and military elites; the key populist claim of acting for and with the support of 'the people', 'typically identified in nativist, xenophobic, and often explicitly racialized terms' (ibid., p. 303); the identification and 'othering' of internal scapegoats, commonly migrants and ethnic minorities; the promise of decisive action in relation to selected controversial issues, frequently involving those scapegoated 'others', and often undertaken with (the threat of) violence - for instance, the mass extrajudicial killings associated with Duterte's 'war on drugs' in the Philippines (Human Rights Watch, 2020).

A final common element entails direct anti-democratic measures. These can include a centralization of executive powers, especially those of the president, accompanied by a disdain for democratic institutions and processes, notably parliament and the judiciary, and a closing down of civil society opposition, all justified by the rhetorical claim to be directly representing 'the people' (McCarthy, 2019, p. 303). The fact that substantial support for authoritarian populist leaders and movements has occurred in existing democratic countries, not just relatively autocratic ones, has led to a crisis in liberal democracy itself, with fundamental questions raised about why this has happened now. In addressing such questions, one key issue is the relationship between authoritarian populism and neoliberalism. In other words, to what extent is the rise of authoritarian populism due to rising inequalities and the increasingly precarious living conditions for large swathes of the population, with both associated with neoliberal capitalism? Somewhat ironically, if support for right-wing populist leaders has come partly from those low-income groups excluded and 'left behind' by neoliberal globalization, then their policies tend to intensify the self-same neoliberal capitalism - for instance, tax cuts for corporations - that is responsible for the current inequalities and exclusion. In this book, Chapter 5 by Edozie examines how 'neoliberal democracy' has actually undermined democracy and given rise to different forms of 'authoritarian neoliberalism' in various regional contexts. We also explore the topic of 'deepening democracy' in Part VII, thereby considering the prospects for more progressive change through forms of democratic governance that aim both to extend democratic decision-making and reverse social and economic inequalities.

\section{THE BOOK'S CONTRIBUTIONS AND STRUCTURE}

The debates regarding the relationship between socio-economic development and democracy, or political regimes more broadly, remain far from settled. Indeed, they have become more nuanced and complex. The aim of this book is not to bring these debates to an end. Rather, it is to bring together a set of distinguished scholars to examine and explore a variety of pertinent questions and issues from a multidisciplinary perspective. It remains noticeable that much of the literature focuses on the relationship between economic development, especially per 
capita income, and democracy, and relies on a quantitative methodology. In this book, we broaden coverage to explore the relationship between regime types (including democracies and autocracies) and broader development indicators, including poverty and human development, inequality, human rights, corruption and environmental sustainability, as well as economic growth. The research questions around these various topics are largely illustrated by the authors with reference to their own recent research, both qualitative and quantitative. We explore the relationship across different regions of the world, including Latin America, Africa, the Middle East and Asia. We explore debates at times in historical perspective, but also bring the latest thinking to the fore. The book is divided into eight parts. In the remainder of this introduction, we introduce each part and its constituent chapters.

\section{Part I: Definitions and Interlinkages}

Part I on definitions and interlinkages provides foundational discussions about the two key concepts. Comprising four chapters, it begins with two chapters that examine democracy and development as separate concepts. Both are 'essentially contested' concepts, and the authors provide definitional clarity by exploring a variety of meanings in a broad and critical manner.

In Chapter 1, Svend-Erik Skaaning discusses 'democracy' as a contested concept, but one that has a common core. He identifies seven main traditions or conceptions of democracy, with a common electoral core. His typology includes more minimalist versions of democracy, such as electoral democracy, and more substantive conceptions of participatory and deliberative democracy. He also distinguishes between a 'reduced' and a 'comprehensive' version for each conception of democracy. Thus, in addition to the common core, the comprehensive versions cover all defining features, inclusive of significant overlapping aspects, while the reduced versions only include the unique attributes of each conception compared to the others.

In Chapter 2, Eija Ranta explores 'development' as a multidimensional concept, an 'intrinsically complex term with multiple meanings'. She notes that this 'ubiquitous yet slippery concept has provided an overarching framework for imagining and organizing relationships between the privileged North and the impoverished South' for over 70 years. Yet, the genealogy of development can be traced to the early nineteenth century and the advancement of industrial capitalism in Western Europe (Cowen and Shenton, 1996). She distinguishes various mainstream approaches linked historically to the development of global capitalism and Western economic interests, while also highlighting critical alternatives based on the work of post-development and postcolonial scholars. Such radical rethinking is especially necessary in the context of climate change, the unsustainable patterns of global capitalism and an industrial mode of living. Thus, the concept of development has become increasingly contested. The illustrative example of Buen Vivir (living well), arising from the struggles of indigenous movements in Latin America, is explored as an ecological and socio-cultural alternative to mainstream development.

After examining the two key concepts separately, Chapter 3 continues by looking at the multiple and contested interlinkages between democracy and development, while noting the importance of avoiding conceptualizations that define one term in relation to the other. With admirable clarity, Alina Rocha Menocal undertakes the challenging task of untangling this relationship in both directions. First, she examines the extent to which development matters for democracy, focusing on two distinct dynamics: whether socio-economic development is a precondition for the emergence of democracy; and whether development may be needed for 
democratic consolidation. While the relationship between higher levels of economic development and established democracy has been one of correlation and not causation, the type of socio-economic development and how it is distributed amongst the population can have a considerable impact on the quality and resilience of democracy. She then turns to look at the question of whether regime type matters for development. Her review of the literature finds that the evidence linking either democracy or authoritarian systems to developmental performance remains inconsistent and inconclusive. Nonetheless, this is not to suggest that democracy is of little consequence for development. If we accept that as a political regime, democracy is desirable in itself, then the key question becomes, how can democracies, especially in the Global South, deliver on development needs and expectations? This intrinsic quality and desirability of democracy brings into question its separation from development, despite this being heuristically necessary in order to untangle the interlinkages and directions of influence.

In Chapter 4, therefore, Darley Jose Kjosavik provides a critical examination of the hugely influential work of Amartya Sen (1999a) and his concept of 'development as freedom'. In Sen's conceptualization, democracy is both a means and an end of development, and therefore the two cannot be separated. In other words, democracy is itself an essential component of development, while the individual political freedoms associated with democracy are also necessary to achieve other elements of development. In overcoming human deprivation and achieving development, Sen argued for the central role of freedom. Sen's concept of freedom has five elements, including political, social and economic elements, and while these are all interconnected and complementary, it is political freedoms, virtually synonymous with liberal democracy, that are especially instrumental in the achievement of the others. It is through democracy that citizens have the freedom to demand development (Sen, 1999b) as well as the agency to achieve development. As Kjosavik informs us, Sen views democracy as being of universal value in three distinctive ways: (1) intrinsic value, constitutive of human freedom in general; (2) instrumental value, where democratic governments are more responsive to people's demands, relating to his famous notion that there have never been famines in democratic countries with a free press (Sen, 1999a, 1999b); and (3) constructive importance, where democratic participation enables citizens to learn from one another, and society is able to form its values and priorities. Sen's conceptualization of development as freedom, in which democracy and development are intertwined in mutual complementarity, has been foundational to the hugely important concept of 'human development', initiated by the United Nations Development Programme (UNDP) in 1990 with the first of its annual Human Development Reports. Sen's views have not been exempt from criticism, however, and Kjosavik outlines some of the key critiques. Her chapter concludes with her own critical observation that Sen does not delve into the type of democracy that is conducive for development, as understood from the perspective of freedom.

\section{Part II: Capitalism, Democracy and Autocracy}

Part II on capitalism, democracy and autocracy continues with three chapters that explore contemporary capitalism and its relationship with democratic and autocratic polities. As indicated above, analysis of the impact of political regimes on development has been largely undertaken on the basis of a binary classification of countries as either democratic or autocratic. This disregards the different forms of both democracy and autocracy, as well as the overlaps between them in the form of hybrid regimes. Such shortcomings are addressed in different ways in the 
chapters in Part II, with the first examining the contemporary variant of neoliberal democracy and its links with authoritarian neoliberalism, the second looking at the differential impact of varieties of autocracy on economic development, while the third examines how autocratic regimes differ in their human development record.

In a wide-ranging discussion in Chapter 5, Rita Kiki Edozie explores the contradictions between democratic principles and the neoliberal variant of capitalism that has become so dominant (hegemonic) in the contemporary world. Taking the classic works of Joseph Schumpeter ([1942] 2010) and Barrington Moore (1966) as a starting point, Edozie traces the impact of neoliberal capitalism on democracy and autocracy in the contemporary period. Two related but opposing concepts are used to frame the discussion: neoliberal democracy and authoritarian neoliberalism. Neoliberal democracy suggests that neoliberalism is good for democracy, expanding market-based freedoms to the citizen as consumer. Yet, Edozie argues that neoliberal democracy actually undermines democracy - for instance, by a reconfiguration of the state into a weaker and less democratic entity, one that is more vulnerable to populist struggles and conflict. In such ways, neoliberal democracy gives rise to authoritarian neoliberalism. Edozie explores the relationship between neoliberal capitalism and democracy in five different contexts in the contemporary world, arguing that each has led to the rise of authoritarian neoliberalism in the early twenty-first century. She looks at authoritarian regimes in East Asia; 'low-intensity democracies' in transitional countries in the 1980s and 1990s; 'choiceless democracies' in the least developed countries locked into economic conditionality by the international financial institutions; 'pink tide' governments in Latin America in the 2000s, followed in some by the election of right-wing populist leaders in the 2010s; and the crisis of liberal democracy in some Western countries with a rise in support for right-wing authoritarian populism. The chapter concludes, following Bruff (2013; Bruff and Tansel, 2019), that authoritarian neoliberalism has emerged as a dominant regime type around the world. Its impact has been to increasingly destabilize liberal democracy in the West and to stunt prospects for democratic consolidation in the Global South.

Given the declines in democratic freedoms and the rise of authoritarian regimes reported by annual democracy surveys, as noted above, it is appropriate to focus on the variety of autocracies and their developmental performances. In Chapter 6, Carl Henrik Knutsen analyses the historical variation in economic growth outcomes among different types of autocracies. Initially, by analysing quantitative data from more than 180 polities and with time-series extending back to 1789 , he establishes that variation in economic growth patterns - in the shorter and longer term, across and within countries - is higher among autocracies than democracies. Additionally, he finds that autocratic regimes are more likely to experience economic crises, and therefore democracy acts as a 'safety net' that gives some protection against the worst economic development outcomes. Subsequently, by taking four categories of autocracies - single-party regimes, personalist regimes, military regimes and monarchies he assesses the explanations for why some autocracies have higher growth rates than others. His findings here are that single-party autocracies have higher growth rates than personalist regimes and monarchies. Related to this is that higher degrees of (ruling) party institutionalization also correlate positively with growth in autocracies. Somewhat surprising is the finding that neither stronger legislative constraints on the autocrat nor the size of an autocratic regime's support coalition correlate positively with growth.

In Chapter 7, Andrea Cassani focuses on the questions of whether and why autocratic regimes might differ in their human development records. The chapter's starting point is that 
just as democracies differ, the non-democratic universe is also 'heterogeneous, encompassing politically closed regimes - such as military, hereditary and one-party autocracies - and so-called electoral autocracies, which in turn range from hegemonic party to competitive systems'. Utilizing data on school enrolment and child mortality for the period 1971-2015, Cassani identifies two related causal mechanisms that shape the relationships between autocratic regimes and human development - namely, the time horizon of leaders and the political survival strategies they adopt. He argues that political survival and time horizon are the two key factors that influence the importance autocrats attach to citizens' living conditions. On the one hand, the more an autocrat needs performance-based legitimation, the greater the attention he or she is likely to pay to citizens' living conditions. On the other hand, the longer an autocrat's time horizon, then the more likely he or she will be committed to improving citizens' living conditions. The chapter's main conclusion is that 'competitive autocracies and monarchs achieve better human development results' than their non-competitive counterparts. In competitive autocracies where the political environment is relatively liberalized, governments tend to be more dependent on popular support and are therefore likely to be more attentive to citizens' living conditions. Time horizons are also important because the longer time horizon that monarchs typically enjoy shifts their priorities from the short to the medium/long term, and thus from predation to human capital investment in healthcare and education. These observations, Cassani notes, emphasize the importance of going beyond the democracyautocracy dichotomy to paying more attention to the institutional variations that characterize the non-democratic universe when seeking to understand the relationships between regime types and human development.

\section{Part III: Regional Perspectives}

In Part III on regional perspectives, we turn to look at how issues of democracy and development have played out in different regional contexts. Quantitative studies of the large-N variety have the advantage of substantial cross-country comparison, but by their nature are unable to take context into account, while qualitative country case-studies can provide detailed accounts based on the specific context, but with generalizability of findings being problematic at times. A regional perspective allows us to explore commonalities and differences within a region, as well as considering possible regional transmission effects from neighbouring countries. We cover Africa, Latin America, Asia and the Middle East, with a final chapter on Islam and its impact on democracy and development in different regional contexts.

In Chapter 8, Michael T. Rock and Marc Howard Ross use four different measures of democracy (with particular focus on majoritarian democracy) to explore the question of whether democracy has contributed to increased economic growth in Africa. This question is of fundamental interest because not only has there been an increase in the number of relatively well-established democracies in sub-Saharan Africa during the last three decades, but also democratization coincided with a robust revival in economic growth. Their empirical findings point to a weak connection between majoritarian democracy and growth, at best. At worst, majoritarian democracy has had no effect on growth in Africa. This led to the chapter's conclusion that democratization has neither strengthened nor slowed economic growth in Africa.

In Chapter 9, Augustin Kwasi Fosu focuses similarly on the experiences of Africa, but looks at the importance of democracy for development more broadly during the post-independence period, inclusive of economic growth and human development. On the basis of those experi- 
ences, he seeks to identify the possible challenges ahead. Based mainly on the extant literature, including his own research, his findings are more positive than those of Rock and Ross. Development measures have improved since the mid-1990s, notably per capita GDP, human development indicators and poverty reduction, while various measures of democracy have also improved since the late 1980s and early 1990s. Most pertinently, there is 'credible evidence that the higher growth and development could be attributed, at least in part, to Africa's improved democratic dispensation'. In particular, a major explanation for this positive association appears to be the ability of 'advanced-level democracy' to provide greater prevalence of political stability and reasonably market-friendly policies. In terms of possible future risks, it is noted that ethnicity has been a major culprit for the dismal historical growth performance in African countries, and argues, first, that 'institutional quality' is crucial for resolving ethnic conflicts and, second, that multiparty democracy can provide the required institutional basis in ethnically fragmented societies. Further, the chapter concludes by highlighting the need to attenuate any potential risks of democratic backtracking by African countries in order to sustain the gains in growth and development.

In Chapter 10, Giovanni Carbone and Alessandro Pellegata investigate the relationships between the modes of leadership selection in Africa and economic growth in the region. The main aim was to investigate the question of whether the means by which African rulers attain and leave office (that is, via guerrilla takeovers, coups d'état, competitive elections, dynastic successions, or in some other way) affect the economic growth of their countries. Their empirical investigation is based on an original dataset compiled by the same authors (see Carbone and Pellegata, 2017, 2018, 2020) - namely, the Africa Leadership Change (ALC) dataset - which maps all leadership handovers that occurred in all countries in the region from 1960 to 2018 . Their findings show that how African leaders gain office and retain it has implications for the economic growth prospects of their countries, with democratically elected leaders standing a much better chance of outperforming their unelected peers. The key causal mechanism here is not so much about the extent of democratic consolidation in its broader conceptualization, but instead the mere organization of regular elections, which contributes to shaping the incentives of leaders and ultimately shapes their effort towards improving economic performance. In this case, and as the authors note, 'even multiparty elections short of democracy - namely, voting that fails to meet minimal (Schumpeterian) procedural standards for democracy - are likely to produce some impact on economic growth'. Nevertheless, the extent of a country's experience with voting, the degree of democratic maturity and the extent to which elections lead to power alternations are all important in enhancing the economic performance of democratically elected leaders in Africa. The chapter's main conclusion is that '[e]conomic growth evidently responds to the conditions under which government leaders are selected in Africa'.

In Chapter 11, Luis Angosto-Ferrández offers a deep historical account of the relationship between democracy and development in Latin America. The chapter starts by reminding us of the wide sociological diversity and political divergences that characterize the region, suggesting that treating Latin America in a homogeneous fashion will be analytically unsound and potentially misleading. Keeping this caveat in mind, Angosto-Ferrández focuses on exploring five key dimensions of the interrelationships between processes of democratization and socio-economic development in the continent. These are: the question of populism in the analysis of the so-called post-neoliberal shift; the definition of state/civil society relations in the configuration of democratic and development models; geopolitics, regionalism and sovereignty; neo-extractivism and alternative development; and the role of production of and 
access to information in debates on democratization. Angosto-Ferrández argues that as an overarching political question, the post-neoliberal shift brought 'the state back' into the politics of democratization and development in the continent. Nevertheless, the extent to which state-centrism may consolidate as a lasting paradigm for social development in the region remains unclear, given the antagonistic forces that continue to traverse most Latin American countries.

In Chapter 12, Aurel Croissant and Lars Pelke focus on the Asia-Pacific region, comprising South, Southeast and Northeast Asia. This region is of particular importance for discussions on the democracy-development debate because the experiences of many countries tend to defy simplistic assumptions regarding the relationship between democracy and development. In particular, the region appears to contradict 'the widely held view that "democracy does a better job in raising living standards in poor countries than does authoritarian government" (Halperin, Siegle and Weinstein, 2010, p. 1)'. Based on a sample of 20 countries in the region, Croissant and Pelke find that variations in state capacity have been the main driver of economic development. Their results show that irrespective of the level of electoral democracy, it is countries with better legal systems and stronger state capacity that tend to perform significantly better. In contrast, the level of 'electoral democracy', they observe, does not appear crucial in shaping economic development outcomes: "countries with more "electoral democracy" do not tend to perform better in economic development'. From the policy perspective, these findings imply that in terms of promoting economic development, 'the effects of introducing or strengthening elements of electoral democracies are far less relevant than strengthening the rule of law and state capacity'.

In Chapter 13, Imad Salamey focuses on the Middle East and North Africa (MENA) region where most countries have been able to sustain relatively high levels of human development in the context of non-democratic governments, suggesting that democracy is not a necessary condition for development. As Salamey points out, the Human Development Index (HDI) of all Arab states is above the medium average, and Arab Gulf states have a particularly high HDI. Yet, in general, Arab states have continued to rank very low on democratization, scoring an average of 3 out of 10 in The Economist's Democracy Index 2018. Salamey's main aims in this chapter are to explain the reasons behind the persistently high levels of democratic deficits in the MENA region, and deepen our understanding as to why the general lack of democratization has not significantly held back socio-economic development in the region. Salamey first demonstrates the limitations of dominant interpretations (including colonialism and oil abundance) of the development trajectories of the region. He argues that certain features of communitarianism that entangle the individual, social class and the nation are best placed for understanding the development trajectories of the MENA region in the context of limited democratization. Salamey concludes that in a chronically divided and turbulent MENA region, the wedge between development and democracy is destined to widen. Thus, and under such a regional context, development is primarily driven by communitarian interests and determined by corresponding political bargains. This implies that democratization may not necessarily be the best response to contemporary challenges in the MENA region. Instead, development actors may do better by prioritizing communitarian dialogue, cooperation, cohesion, power sharing and consensus-building as a means to stabilization and development in the region.

Finally in this part of the book, in Chapter 14, Michael T. Rock and Soli Ozel offer a critical analysis of the relationship between Islam, democracy and development, focusing on economic growth. Their starting point is that although Muslim majority countries often do 
not appear to be particularly hospitable to democracy or development, the specific causal mechanism at play remains debatable. They pose two questions. First, is the poor performance the product of Islam, or is it rather the result of some salient political features in the Muslim world? Second, why are some Muslim countries better at democracy and development than others? After a detailed review of the theoretical and empirical literature on the first question, the authors use a panel dataset to test the hypotheses that Islam is incompatible with democracy and slows growth. They found little empirical support for either hypothesis regarding Islam, although Arab Muslim countries are less democratic and grow slower than their non-Arab Muslim counterparts. Rock and Ozel address the second question by utilizing an elite consensus-conflict analytical frame to uncover the sources of difference in democracy and development outcomes in Egypt and Indonesia, two similarly placed countries with very different democracy and development outcomes. Their findings again show that the growth and democracy differences in these countries have little to do with Islam. Instead they are the result of different state-building strategies and the ability and willingness of secular nationalist and Islamic elites to cooperate on a democracy project. When elites are consensually united, as in Indonesia, democracy and development can go hand in hand. When elites are virtually at war with each other, as in Egypt, cooperation on a democracy project becomes almost impossible. Unfortunately, high levels of elite factionalism also spill over into state-building and development strategies in ways that further undermine prospects for economic growth.

\section{Part IV: International Institutions and Aid Policy}

Part IV on international institutions and aid policy considers ways in which democracy and development were linked in the post-Cold War agenda of international institutions, notably in their aid policies. This was most evident in the policies of 'political conditionality' that were introduced in the early 1990s (Crawford, 2001; Stokke, 1995), and relates closely to the 'new orthodoxy' at that time, as discussed above. In theory at least, this made the receipt of development 'aid' by developing countries conditional on respect for human rights and other democratic principles. It was also an important element of the accession process to the European Union for former communist countries in Central and Eastern Europe. Policies involved both 'carrot and stick', the promise of democracy assistance and the threat of aid suspension for developing countries, and the prospect of EU membership (or not) for accession countries. While the accession of Central and Eastern European states to EU membership in the 2000s is widely regarded as an example of successful political conditionality (Schimmelfennig and Scholtz, 2008), policy outcomes elsewhere were mixed, at best, and subject to greater criticism with respect to developing countries (Crawford, 1997). Related aspects of this policy agenda continued to be influential, however. First, with regard to multilateral institutions, the World Bank's role in the post-Cold War policy shifts had been to promote the concept of 'good governance' (Crawford, 2001), which became associated in particular with anti-corruption measures. The World Bank's influence affected other international institutions, including the EU, and anti-corruption became a more central element of EU external and internal policies. Second, the linkage of human rights to development was taken up positively by many non-governmental development organizations in the 1990s, with increasing advocacy of a human rights-based approach to development (Cornwall and Nyamu-Musembi, 2004, pp. 1425-30; Gready and Ensor, 2005; Mitlin and Hickey, 2009). These two themes are taken up in the two chapters in this part of the book. 
In Chapter 15, Ina Kubbe and Liljana Cvetanoska discuss the role of the EU in promoting democracy and fighting corruption, particularly the misuse of EU funds, among its Central and Eastern European (CEE) member states. While the EU has made concerted efforts in tackling corruption among its member states, many CEE member countries continue to suffer from relatively high levels of corruption, with countries like Bulgaria and Hungary even recording notable declines in terms of their respect for democracy and the rule of law. In this chapter, the authors seek to enhance understanding of the impact (or lack thereof) of EU measures on corruption control and the implications of this for democracy in Bulgaria and Hungary. They argue that despite the availability of a number of anti-corruption tools available to the EU, the Union's success in preventing the misuse of its funds among member states has been limited. In part, this is explained by weaknesses in the EU's two main anti-corruption tools, namely the European Anti-Fraud Office (OLAF) and the newly introduced European Public Prosecutor's Office (EPPO). Moreover, the incentives for following EU anti-corruption requirements usually decline significantly once a country obtains membership status - the EU has less to offer as a reward after a country becomes a member, the reason why its political conditionality was successful in the first instance, and also has limited options for punishments in cases of non-compliance. In addition, the EU's reluctance to use punishments (e.g., freezing funds), further weakens its position as an anti-corruption actor which causes additional problems for protecting the Union's financial interests.

In Chapter 16, Bård Anders Andreassen examines the interrelationship between human rights and development. He notes that the linkage between the two was absent for many years, like 'ships passing in the night', as stated by Philip Alston (2005) in describing the relationship between the Millennium Development Goals and human rights. Yet, from the late 1990s, this rapidly changed, with many non-governmental development organizations, as well as some multilateral organizations and bilateral agencies, organizing their development strategies around human rights laws and principles. This became known as the human rights-based approach to development and became a predominant approach in the 2000s, especially amongst international non-governmental organizations (NGOs), as noted above. Civic engagement was also an important aspect of the rights-based approach, with a linkage here to democratic processes, with an emphasis on the agency of disadvantaged and marginalized groups, such as women, children and people with disabilities, to secure those rights pertinent to their situation. Although appearing to be a relatively progressive approach to development, critical voices highlighted a practical deficit, claiming that there was plenty of rhetoric about the advantages of merging human rights and development, but little evidence of its positive impact. For such critics, rights-based approaches are rather better understood as rights-framed approaches - that is, approaches using rights language when it is strategically convenient, but not as genuinely new platforms for local, national and international development efforts. Andreassen challenges such criticisms and suggests the need for rights-based approaches and their application by NGOs to be understood as complementary value-based evaluative models that provide guidance to development programming and practice, rather than perceived in isolation from other approaches to development (e.g., economic growth models). For Andreassen, this perspective pushes us to understand human rights approaches as representing a broadening of the value foundation of development by expressing expectations of human rights accountability to states and international institutions. 


\section{Part V: Democracy and Conflict Transformation}

In four chapters, Part V turns to important issues of democracy and conflict transformation. Peace is regarded as a prerequisite of development. Therefore in post-conflict settings, the key question concerns the most appropriate political system to re-establish peace and stability, not as only desirable in itself, but also essential for renewed socio-economic development. The conventional wisdom may be that a democratic polity offers the institutional means to make political decisions in a non-violent manner. But the political competition integral to democratic systems can also generate conflict, especially in societies divided along ethnic or religious lines. This leads to the question of which form of democracy or institutional design is most suitable for post-conflict settings. There is some consensus that the majoritarian model of 'winner takes all', as epitomized by the UK's Westminster model, is particularly inappropriate. In contrast, Arend Lijphart $(1985,2008)$ has proposed his consociational model as a means of accommodating social divisions through recognition of the existence of such divisions, and power sharing amongst different groups. Consociationalism has generated much debate about its advantages and disadvantages, with Donald Horowitz (2000) putting forward an alternative 'integrative approach' that aims instead to suppress ethnic identity and promote inter-ethnic cooperation.

In Chapter 17, Allison McCulloch engages with this debate concerning the design of political institutions in post-conflict societies. In particular, her chapter addresses the question of whether and how consociation, as an institutional design, can help sustain democracy in societies characterized by deep ethnic divisions. Drawing evidence from a range of countries, the chapter strongly demonstrates consociation's mixed record in fostering democratic stability. McCulloch argues that these varied outcomes are not surprising because, as an institutional design, consociation is inherently characterized by two sets of countervailing incentives, one that encourages compromise and cooperation and one that encourages intransigence and outbidding. As she notes, 'Whether or not consociation facilitates democracy, peace and stability in divided societies is contingent on which set of countervailing incentives is activated - those that pull in the direction of cooperation or those that push in the direction of intransigence'. In assessing these contrasting outcomes under consociational rules, four explanatory factors are highlighted: how consociations come into being; the fit between institutions and context; the inclusiveness of consociational rules; and their flexibility in responding to shifting dynamics over time. Although the potential of other alternative institutional models is explored, the chapter concludes by explaining why, despite a mixed track record, consociation remains an important avenue for establishing and maintaining democracy in divided societies.

In Chapter 18, Alpaslan Özerdem looks at post-conflict reconstruction and democracy promotion. He notes how post-conflict reconstruction has been dominated by international actors, especially post-Cold War. Their approach has been heavily influenced by the liberal peace agenda, with its two main elements of 'democracy' and 'market economy'. He notes that the holding of 'free and fair' elections is regarded as the primary goal of political reconstruction by external actors, yet highlights three problematic issues: the timing of elections; socio-political and security conditions for elections; and the nature of the electoral system. Interestingly, he also explores how post-conflict reconstruction activities are themselves used as a means for the promotion of democratization efforts in war-torn societies. While this could be an effective means of promoting democracy in post-conflict contexts, Özerdem argues that the manner in which the liberal peace agenda is implemented has led to 'major failures'. 
Özerdem also notes how the rule of law features prominently in the post-conflict reconstruction strategies promoted by international organizations and bilateral 'donor' agencies. One key element is transitional justice programmes that attempt to address human rights violations committed during armed conflicts.

In Chapter 19, Matthew Evans examines the concept of transitional justice in greater detail, including its shortcomings. One criticism of the transitional justice paradigm is that it does not address the underlying causes of conflict, often development related, which may endure post-conflict. Evans explores the relationships between transitional justice, transformative justice, democracy and development. In particular, he considers the extent to which transitional justice and development could become mutually constitutive, as well as challenges to this. He argues that established, narrow approaches to transitional justice are less likely to contribute towards development compared with broader transformative justice approaches, which themselves have more expansive goals such as the realization of socio-economic rights and maximization of freedom. The chapter concludes by positing that for mutual reinforcement of transitional justice and development in post-conflict or post-authoritarian contexts, not only are more expansive notions of both concepts necessary, but the facilitation of democratic participation of affected communities is required to prioritize their concerns as opposed to those of elite actors and outside interests.

In Chapter 20, Tom Lodge sets out to highlight the key challenges faced by the newly elected political leadership in post-apartheid South Africa from 1994 onwards. These included questions of how to institutionalize democracy after more than a decade of insurrectionary politics and a long history of authoritarian rule, as well as how to reduce deep-seated social and racial inequalities and extraordinarily high levels of unemployment. Overall, Lodge argues that successive African National Congress (ANC) governments have been successful in achieving their electoral promise of ensuring 'a better life for all', both in terms of institutionalizing democracy and in enhancing the socio-economic well-being of citizens, but with some significant qualifications that limit both the democratic and developmental progress. From the perspective of democratic consolidation, progress includes organizing increasingly honest elections, a progressively more robust parliamentary opposition, independent high courts, and protection of civil liberties that allow for vigorous expression of public displeasure. However, the socio-economic development record is mixed: access to formal jobs remains limited, though citizens now enjoy better social security and wider access to healthcare and education than 30 years ago. Whether progress in democratization has helped to foster development outcomes remains an open question. Positively, government has become more responsive to the needs of poor people, but meeting basic needs is not altogether the same thing as fostering development. Indeed, ANC compliance to demands within its own constituency helps to explain some of its allocative choices that have constrained broad-based development. Thus, patronage-based public spending, aimed at appeasing important political constituents and allies such as the Congress of South African Trade Unions (COSATU), along with internal party factionalism, have encouraged a proliferation of rent-seeking behaviour that has had adverse implications on key development outcomes.

\section{Part VI: Inequalities and Democracy}

Part VI of the book focuses on inequalities and democracy, a hugely important topic given that rising and enduring inequalities challenge and compromise various elements of liberal democ- 
racy. In Chapter 21, in a wide-ranging examination of the problematic relationship between democracy and inequality, Alina Rocha Menocal characterizes inequality as democracy's catch-22. She begins by demonstrating why inequality is corrosive to democracy, arguing that 'inequality undermines the quality and resilience of democratic governance, notably creating imbalances in voice, representation, opportunity and access that disenfranchise segments of the population, undermine trust in (and support for) democratic institutions, and increase support for populism, extremism, and/or violent conflict'. In short, rising social and economic inequalities, including between different social groups, can lead to both a crisis in democracy and the rise of right-wing, authoritarian populism in various parts of the globe. Despite the positive role of liberal democracy perceived by analysts like Amartya Sen, Rocha Menocal observes that, 'there is nothing about democracy that automatically tackles such inequalities', which is why in her view inequality is democracy's catch-22. Nonetheless, she notes that in some instances democracies have been able to tackle inequality and exclusion, and she concludes the chapter by outlining some key factors that have enabled such progress, inclusive of sound policy making, state capacity, elite commitment, coalition building and social mobilization.

One notable inequality within democratic polities is that between women and men, with unequal participation and representation in many different political spheres from government and parliaments to political parties and civic associations. While the extension of the franchise to women was achieved by women's movements such as the Suffragettes in the UK in the early twentieth century, women's representation in parliaments worldwide has remained low. Out of 192 countries, only three had over 50 per cent female representatives in February 2019 Rwanda (61.3 per cent), Cuba (53.2 per cent) and Bolivia (53.1 per cent) (Inter-Parliamentary Union, 2019). In Chapter 22, Gretchen Bauer examines the links between gender inequality and democracy in Africa. Particular attention is paid to the related questions of whether democracy has failed women with regard to redressing the problem of women's unequal representation in politics; and whether democracies are more likely to be characterized by greater female representation in their legislatures than autocracies. The chapter concludes that in terms of political empowerment, women continue to lag behind men in important indicators such as representation in parliament and other institutions of government. The chapter acknowledges the important role of affirmative action interventions, such as electoral gender quotas, in bringing more women into politics and decision-making, with women even achieving parity with men in some instances. However, these achievements have been observed in both democracies and non-democracies alike, not only in Africa but also in other parts of the world. This, Bauer notes, calls into question the idea of a necessary link between democracy and equality, including gender equality.

While most research on inequality has focused on income and wealth inequalities between individuals or households, what is termed 'vertical inequality', there has been less attention paid to 'horizontal inequalities' - that is, those inequalities between groups of people, for example based on culture or ethnicity (Stewart, 2016). Horizontal inequalities include unequal access to social services such as education and healthcare, and their association with poverty traps and conflict (Stewart, 2008) make them particularly significant. In Chapter 23, Frances Stewart explores the relationship between horizontal inequalities and democracy. Horizontal inequalities (HIs), Stewart notes, are especially relevant to political outcomes given that 'groups are in general more powerful actors in politics than individuals by themselves'. The chapter identifies a two-way relationship between democracy and HIs: while the presence of high HIs might influence whether democracy occurs and is sustained, the presence of democ- 
racy may in turn result in the adoption and implementation of policies that affect HIs. Given the many subtypes of the concept of democracy, she argues further that the relationship between HIs and democracy also partly depends on the type of democracy in question. Drawing on case studies from a wide range of countries, Stewart concludes that the degree of stability of a country's democracy is shaped by the depth of its political and socio-economic HIs. As she puts it, low HIs are most conducive to stable democracy, while 'high HIs can lead to the breakdown of democracy, especially where there are both political and socio-economic inequalities with a major group deprived in both dimensions'. The chapter highlights a two-way causal mechanism in the democracy-HI relationship: sharp HIs make it more likely that democracy will break down, while democratic institutions are also more likely to be associated with the adoption of policies to reduce HIs, including power sharing and affirmative action. Overall, however, how this relationship plays out in practice depends on the demographic composition of a country and the nature of its democratic institutions.

\section{Part VII: Deepening Democracy}

Part VII turns to look at deepening democracy. Advocacy of a deeper and more substantive form of democracy has long existed. Its roots can be traced back to the origins of democracy in ancient Athens in the fifth and fourth centuries BC and, in more modern times, to the ideas of the eighteenth-century political theorist Jean-Jacques Rousseau, who was critical of the limitations of representative democracy. In the contemporary world, a more substantive form of democracy is commonly referred to as direct democracy or participatory democracy (see Chapter 1 by Skaaning). Of course, the direct participation in collective decision-making of all citizens was easier to realize in the Athenian demos or in the small city-states of eighteenth-century Europe than in today's large, complex modern states. Consequently, much theory and practice concerning the deepening of democracy through greater citizen participation focuses on the local level. This is reflected in three recent trends - participatory budgeting; the role of civil society in democratization; and decentralization. Three chapters follow on these respective issues. Additionally, Chapter 27 by Jesse Ribot in Part VIII provides a further discussion of decentralization in the context of local democracy and natural resource governance.

In Chapter 24 on participatory budgeting, Yves Cabannes examines this remarkable phenomenon that emerged in 1989 in Porto Alegre in Brazil and rapidly spread throughout Brazil and Latin America, as well as transmission to Europe and elsewhere globally. Cabannes states that in 2018 there were more than 6000 instances of participatory budgeting (PB) across at least 40 countries. His chapter examines the extent to which both marginalized and socially excluded groups are engaged in PB and benefit from it, thus focusing on the potentially more transformative aspects of PB. He does this by exploring the extent to which PB has 'reversed' social, spatial and political priorities in the distribution of public resources in favour of disadvantaged groups. His data span three decades of PB practice, and, as part of a larger World Bank study, include 11 selected case studies from different regions in the world that have addressed the needs of disadvantaged groups. Conclusions are three-fold and generally positive. First, PB is not static and has evolved over time. In particular, many cities have moved from simpler PB modalities to more comprehensive and complex ones and thereby developed the capacity to reach disadvantaged groups. Second, PB with people is preferable to $\mathrm{PB}$ for people. In other words, the active participation of marginalized and excluded groups 
themselves is key to achieving social advancement. However, this may require the capacity of such social groups to modify the established PB rules. Third, in terms of redistributive aspects, findings are positive in many cases, with evidence of the reversal of social and spatial priorities. Cabannes notes that this answers, at least partially, the concerns of some scholars that over time PB may have been moderated and depoliticized, and has thereby lost its capacity for redistribution.

The role of civil society organizations (CSOs) in both democratization and development has been a key topic of policy practice and academic interest since the 1990s, especially in relation to democratic transition and consolidation. Motivations underpinning this promotion of CSOs have been varied (Crawford and Abdulai, 2011). From a radical democracy perspective, an enhanced role for CSOs suggested higher levels of political participation by citizen groups, potentially greater representation of the interests of marginalized groups, and improved prospects for holding government to account. All this corresponded with a democratic deepening perspective. Yet, advocacy of the role of NGOs in particular also tallied with a neoliberal viewpoint in which the state was perceived negatively, with non-state actors, inclusive of both NGOs and the private sector, seen as the key agents to achieve development and hold government in check. This accounts for the strengthening of civil society in general, and NGOs in particular, as an important plank of Western governments' development aid policies (ibid.).

In Chapter 25, Badru Bukenya examines some of these ambiguous issues. In particular, he adds to the literature on the role of NGOs in democratic consolidation, especially in public policy advocacy in the interests of marginalized groups. He does so by analysing the efficacy of NGOs in influencing government policy and legislation in relation to Uganda's oil sector. He addresses three main issues: the strategies employed by NGOs in policy advocacy; the outcomes of policy advocacy efforts; and the factors that influence NGO performance. His analysis is situated within Uganda's relatively unfavourable political environment, characterized as a 'hybrid' regime, partly democratic and partly autocratic, where the government is quite intolerant of alternative views and has overseen the passage of restrictive laws to manage NGOs. Bukenya outlines how NGOs attempted to play a central role in shaping oil sector laws and governance arrangements, mainly by working with parliament. Yet, his findings are that NGOs' achievements were minimal. This is largely attributed to the unfavourable political context where their operations were closely controlled by the state through a strict legal framework, confirming the observations of other researchers about the limited policy advocacy of NGOs in relatively authoritarian contexts. Yet, the NGOs were also perceived as having internal weaknesses, notably their inability to mobilize resources locally and hence their dependence on external funding from 'donors', enabling the ruling elite to question their legitimacy and accuse them of promoting foreign interests, thus reducing policy impact. Coordination amongst NGOs was also weak, resulting in unproductive competition. In such contexts, the prospects for NGOs contributing to democratic consolidation are low. Indeed, Bukenya concludes that the political environment was the main factor that shaped the (in) effectiveness of NGOs' policy advocacy in Uganda, and suggests that a way forward for NGOs in semi-authoritarian contexts, like that of Uganda, may be to adopt strategies that secure them 'insider' rather than 'outsider' status in relation to government. However, that would also seem to pose dangers of compromise and co-option in relation to policy advocacy in the interests of the marginalized.

Another longstanding yet ambiguous agenda is that of decentralization. Advocacy of decentralization of government by a variety of actors and institutions pre-dates the end of the Cold 
War, with a 'wave' of decentralization since the mid-1980s. There was a remarkable consensus on its desirability. The political left was generally in favour from a democratic deepening perspective in which local citizens could exert greater influence on political decision-making at the local level. The emphasis here was on devolution of powers from central to local levels as a form of democratic decentralization in which government was brought closer to the people. Yet, decentralization was also promoted vigorously by international institutions and Western governments as part of their neoliberal agenda to reduce the powers of what they perceived to be an overcentralized and inefficient state. Here the emphasis was more on administrative decentralization (or deconcentration) and fiscal decentralization, ostensibly to enhance state efficiency and financial accountability, as well as the transfer of local service provision from the public to the private sector. One outcome of this widespread enthusiasm for decentralization was that, by 2005,80 percent of all developing and transition countries were undertaking some form of decentralization (International Council for Human Rights Policy, 2005, p. 11).

In Chapter 26, Sylvia I. Bergh examines the phenomenon of decentralization and its impact on local development, illustrated by a case study of regionalization in Morocco. She begins with a discussion of the types, drivers, promises and risks of decentralization. Then, drawing from Faguet and Pöschl (2015), she outlines four ways in which decentralization can theoretically enhance local development, noting, however, that empirical evidence on these relationships remains sobering. She adds to existing studies with her own in-depth qualitative study of regional decentralization in Morocco. This focus on the regional level is itself of interest, given the predominance of local government studies in the decentralization literature. Constitutional reforms were enacted in Morocco in 2011, which established 12 new directly elected regional assemblies and transferred substantial developmental responsibilities to them. Bergh explores a range of issues regarding these new regional government bodies, including governance and democracy issues, financial issues, regional planning issues and the relationship between devolution and deconcentration reforms. Rather than enhancing democratic institutions and processes, her analysis suggests that decentralization represents an exercise in 'upgrading authoritarianism'. Under pressure in 2011 from within and outside the country to democratize in the context of the Arab Spring, the king has sustained his powers through a clever creation of elected bodies and paying lip service to decentralization, while also finding ways to prevent full implementation of reforms, notably through the establishment of more powerful parallel (deconcentrated, sectoral) institutions that remain accountable to the monarch and central government. The chapter thus indicates the 'paradox of decentralization'. The prospects for democratic deepening can be compromised and undermined by a range of factors, resulting in opposite outcomes, including a strengthening of central government and at times of autocratic structures.

\section{Part VIII: Democratic Development and the Environment}

Finally, in Part VIII we turn to issues of democratic development and the environment. In Chapter 27, Jesse Ribot examines questions of local democracy and natural resource governance. This chapter follows on well from that by Bergh. Ribot takes another critical look at decentralization, positing the institutional structures and processes that must be available for local democracy to blossom. He does so through the lens of decentralized decision-making over natural resources, especially forestry. His starting point is that although elected local governments have been legislated in many countries, local democracy has rarely been implemented. 
To understand this, and to suggest a way forward, he introduces the 'choice and recognition' framework. This acknowledges that higher-level agents, notably central governments as well as international development agencies, can choose either to foster elected local governments or other parallel institutions such as customary authorities, line ministries or NGOs. In making such choices, the higher-level bodies are recognizing different kinds of local authorities, either governmental or non-governmental, and thus empowering them. This in turn shapes three key aspects of democracy: representation, citizenship and the public domain. Ribot illustrates his discussion with examples from the forestry sector. He notes how many internationally funded forestry projects, including those related to climate-change adaptation, chose not to engage with or recognize existing elected local governments, but instead worked with customary chiefs or project-created local committees, thus circumventing local democracy. In Senegal, for instance, although decentralization and forestry laws give elected local governments (rural councils) the right to manage natural resources, a donor-funded biodiversity project chose to create 'village committees' to manage the reserve, marginalizing the elected rural council. He notes that 'when local people are not represented in decisions over forestry interventions, they disengage from projects... [and] often resist or sabotage projects... while elites are more able to capture benefits'. The implications for local democracy are clearly negative. Other examples are given where recognition of the role of local governments enabled them to become more representative of and responsive to the needs and demands of local citizens. In concluding, Ribot asserts that giving attention to institutional choice enables greater understanding of how local democracy can be helped (or hindered), with the aim of creating representative local government with meaningful discretionary powers and subject to influence by engaged citizens. In such ways democracy can be deepened and the interests of the majority poor addressed.

In Chapter 28 on democracy, ideological orientation and sustainable development, Peter Söderbaum encourages researchers to apply an alternative approach to issues of sustainable development to that of mainstream neoclassical economics. Sustainable development has become a vision for the world since the Brundtland Report of 1987, and currently encapsulated in the UN's Sustainable Development Goals. Yet, current practices remain unsustainable, most notably in relation to climate change, and he notes that 'present unsustainable trends have come about during a period when neoclassical economics as a paradigm and neoliberal ideology have been dominant'. Therefore, in considering the role of economics, Söderbaum argues that the technocratic orientation of mainstream neoclassical economics should be downplayed in favour of a democracy-oriented alternative perspective. This entails an institutional version of 'ecological economics' or 'sustainability economics' that promotes pluralist thought in the sense of comparing and assessing alternatives. In contrast to the positivist paradigm that underpins neoclassical economics with its assumption of value neutrality, 'democracy-oriented economics' encourages critical engagement with differing value-based and ideological standpoints, including established ones, in a manner that respectfully subjects them to contestation and facilitates multidimensional learning. Simultaneously, he posits, 'democracy is strengthened by listening to many voices and respecting different viewpoints'. While not rejecting potential contributions from mainstream approaches, he argues that it is imperative to explore and articulate alternative ideological viewpoints to that of neoliberalism in order to inform debate and dialogue about issues of sustainability and sustainable development in a democracy-enhancing manner. 


\section{REFERENCES}

Abdulai, A.-G. and G. Crawford (2010), 'Democratic consolidation in Ghana: prospects and challenges?', Democratization, 17 (1), 26-67.

Abdulai, A.-G. and S. Hickey (2016), 'The politics of development under competitive clientelism: insights from Ghana's education sector', African Affairs, 115 (458), 44-72.

Alston, P. (2005), 'Ships passing in the night: the current state of the human rights and development debate seen through the lens of the Millennium Development Goals', Human Rights Quarterly, 27 (3), 755-829.

Amsden, A.H. (1989), Asia's Next Giant: South Korea and Late Industrialization, New York: Oxford University Press.

Beetham, D. (1994), 'Key principles and indices for a democratic audit', in D. Beetham (ed.) Defining and Measuring Democracy, London: SAGE Publications, pp. 25-43.

Beetham, D. and K. Boyle (1995), Introducing Democracy: 80 Questions and Answers, Cambridge, UK: Polity Press.

Bruff, I. (2013), 'The rise of authoritarian neoliberalism', Rethinking Marxism: A Journal of Economics, Culture \& Society, 26 (1), 113-29.

Bruff, I. and C.B. Tansel (2019), 'Authoritarian neoliberalism: trajectories of knowledge production and praxis', Globalizations, 16 (3), 233-44.

Carbone, G. and A. Pellegata (2017), 'To elect or not to elect: leaders, alternation in power and social welfare in sub-Saharan Africa', Journal of Development Studies, 53 (12), 1965-87.

Carbone, G. and A. Pellegata (2018), 'Researching the dynamics of leaders' replacement: the Africa Leadership Change (ALC) dataset', European Political Science, 17 (2), 187-210.

Carbone, G. and A. Pellegata (2020), Political Leadership in Africa: Leaders and Development South of the Sahara, Cambridge, UK: Cambridge University Press.

Collier, D. (1979), 'Overview of the bureaucratic-authoritarian model', in D. Collier (ed.), The New Authoritarianism in Latin America, Princeton, NJ: Princeton University Press, pp. 19-32.

Cornwall, A. and C. Nyamu-Musembi (2004), 'Putting the rights-based approach to development into perspective', Third World Quarterly, 25 (8), 1415-37.

Cowen, M.P. and R.W. Shenton (1996), Doctrines of Development, Abingdon: Routledge.

Crawford, G. (1997), 'Foreign aid and political conditionality: issues of effectiveness and consistency', Democratization, 4 (3), 69-108.

Crawford, G. (2001), Foreign Aid and Political Reform: A Comparative Analysis of Democracy Assistance and Political Conditionality, Basingstoke: Palgrave Macmillan.

Crawford, G. and A.-G. Abdulai (2011), 'Liberal democracy promotion and civil society strengthening in Ghana', in C. Hobson and M. Kurki (eds), The Conceptual Politics of Democracy Promotion, Abingdon: Routledge, pp. 131-50.

Crawford, G. and A.-G. Abdulai (2012), 'Democratization, poverty and inequality', in J. Haynes (ed.), Routledge Handbook of Democratization, London: Routledge, pp. 353-67.

Faguet, J.-P. and C. Pöschl (2015), 'Is decentralization good for development? Perspectives from academics and policy makers', in J.-P. Faguet and C. Pöschl (eds), Is Decentralization Good for Development? Perspectives from Academics and Policy Makers, Oxford: Oxford University Press, pp. $1-28$.

Freedom House (2020), 'New report: Freedom in the World 2020 finds established democracies are in decline', 4 March, accessed 28 June 2020 at https://freedomhouse.org/article/new-report-freedom -world-2020-finds-established-democracies-are-decline.

Gready, P. and J. Ensor (2005), 'Introduction', in P. Gready and J. Ensor (eds), Reinventing Development? Translating Rights-based Approaches from Theory into Practice, London: Zed Books.

Halperin, M., J.T. Siegle and M. Weinstein (2010), The Democracy Advantage, 2nd edition, New York: Routledge.

Hanson, J.K. (2015), 'Democracy and state capacity: complements or substitutes?' Studies in Comparative International Development, 50, 304-30.

Hickey, S., K. Sen and B. Bukenya (eds) (2015), The Politics of Inclusive Development: Interrogating the Evidence, Oxford: Oxford University Press. 


\section{Research handbook on democracy and development}

Horowitz, D.L. (2000), Ethnic Groups in Conflict, 2nd edition, Berkeley, CA: University of California Press.

Human Rights Watch (2020), 'Philippines' war on drugs', accessed 20 June 2020 at https://www.hrw .org/tag/philippines-war-drugs.

Huntington, S.P. (1968), Political Order in Changing Societies, New Haven, CT: Yale University Press.

Huntington, S.P. (1991), The Third Wave: Democratization in the Late Twentieth Century, Norman, OK: University of Oklahoma Press.

Huntington, S.P. (1997), 'After twenty years: the future of the third wave', Journal of Democracy, 8 (4), 3-12.

International Council for Human Rights Policy (ICHRP) (2005), Local Governance and Human Rights: Doing Good Service, Geneva: ICHRP.

Inter-Parliamentary Union (2019), 'Women in national parliaments', 1 February, accessed 28 June 2020 at http://archive.ipu.org/wmn-e/classif.htm.

Kelsall, T. (2013), Business, Politics and the State in Africa, London: Zed Books.

Khan, M. (2010), 'Political settlements and the governance of growth-enhancing institutions' [mimeo], London: School of Oriental and African Studies (SOAS).

Khan, M. (2018), 'Political settlements and the analysis of institutions', African Affairs, 117 (469), 636-55.

Knutsen, C.H., J. Gerring and S.-E. Skaaning et al. (2018), 'Economic development and democracy: an electoral connection', European Journal of Political Research, 58, 292-314.

Leftwich, A. (1996), 'On the primacy of politics in development', in A. Leftwich (ed.), Democracy and Development: Theory and Practice, Cambridge, UK: Polity Press, pp. 3-24.

Levitsky, S. and L.A. Way (2010), Competitive Authoritarianism: Hybrid Regimes After the Cold War, Cambridge, UK: Cambridge University Press.

Levy, B. (2014), Working with the Grain: Integrating Governance and Growth in Development Strategies, New York: Oxford University Press.

Lijphart, A. (1985), Power-Sharing in South Africa, Berkeley, CA: University of California Press.

Lijphart, A. (2008), Thinking about Democracy: Power-Sharing and Majority Rule in Theory and Practice, Abingdon: Routledge.

Lipset, S.M. (1959), 'Some social requisites of democracy', American Political Science Review, 53, 69-105.

McCarthy, J. (2019), 'Authoritarianism, populism, and the environment: comparative experiences, insights, and perspectives', Annals of the American Association of Geographers, 109 (2), 301-13.

Mitlin, D. and S. Hickey (eds) (2009), Rights-Based Approaches to Development: Exploring the Potential and Pitfalls, Sterling, VA: Kumarian Press.

Moore, B., Jr (1966), Social Origins of Dictatorship and Democracy: Lord and Peasant in the Making of the Modern World, Boston, MA: Beacon Press.

Navia, P. and T.D. Zweifel (2000), 'Democracy, dictatorship, and infant mortality', Journal of Democracy, 11 (2), 99-114.

O'Donnell, G.A. (1973), Modernization and Bureaucratic Authoritarianism: Studies in South American Politics, Berkeley, CA: Institute of International Studies, University of California.

Oxfam (2014), Even It Up: Time to End Extreme Inequality, accessed 28 June 2020 at https://policy -practice.oxfam.org.uk/publications/even-it-up-time-to-end-extreme-inequality-333012.

Pickett, K. and R. Wilkinson (2009), The Spirit Level: Why Equality is Better for Everyone, London: Allen Lane.

Piketty, T. (2014), Capital in the Twenty-First Century, Cambridge, MA: Harvard University Press.

Przeworski, A., M.E. Alvarez, J.A. Cheibub and F. Limongi (2000), Democracy and Development: Political Institutions and Well-Being in the World 1950-1990, Cambridge, UK: Cambridge University Press.

Rueschemeyer, D., E.H. Stephens and J.D. Stephens (1992), Capitalist Development and Democracy, Chicago, IL: University of Chicago Press.

Sargent, G. (2013), 'Inequality is the "defining issue of our time", Washington Post, 4 December, accessed 28 June 2020 at https://www.washingtonpost.com/blogs/plum-line/wp/2013/12/04/ inequality-is-the-defining-issue-of-our-time. 
Schimmelfennig, F. and H. Scholtz (2008), 'EU democracy promotion in the European neighbourhood: political conditionality, economic development and transnational exchange', European Union Politics, 9 (2), 187-215.

Schumpeter, J. ([1942] 2010), Capitalism, Socialism and Democracy, Abingdon: Routledge.

Sen, A. (1999a), Development as Freedom, Oxford: Oxford University Press.

Sen, A. (1999b), 'Democracy as a universal value', Journal of Democracy, 10 (3), 3-17.

Sorensen, G. (1998), Democracy and Democratization: Processes and Prospects in a Changing World, 2nd edition, Boulder, CO: Westview Press.

Stewart, F. (ed.) (2008), Horizontal Inequalities and Conflict: Understanding Group Violence in Multiethnic Societies, Basingstoke: Palgrave Macmillan.

Stewart, F. (2016), 'Horizontal inequalities', in M. Leach, J. Gaventa and P. Justino et al. (eds), Challenging Inequalities: Pathways to a Just World, Paris: UNESCO, pp. 51-4.

Stokke, O. (1995), 'Aid and political conditionality: core issues and state of the art', in O. Stokke (ed.), Aid and Political Conditionality, London: Frank Cass/EADI, pp. 1-87.

Wade, R. (1990), Governing the Market: Economic Theory and the Role of Government in East Asian Industrialization, Princeton, NJ: Princeton University Press.

The Economist (2020), 'Democracy is in retreat', 21 January, accessed 28 June 2020 at https://www.eiu .com/n/global-democracy-in-retreat/. 